Article

\title{
Exploring Political Journalism Homophily on Twitter: A Comparative Analysis of US and UK Elections in 2016 and 2017
}

\author{
Kelly Fincham \\ Department of Journalism, Public Relations and Media Studies, Hofstra University, Hempstead, NY 11549, USA; \\ E-Mail: kelly.fincham@hofstra.edu
}

Submitted: 12 November 2018 | Accepted: 14 January 2019 | Published: 21 March 2019

\begin{abstract}
The tendency of political journalists to form insular groups or packs, chasing the same angles and quoting the same sources, is a well-documented issue in journalism studies and has long been criticized for its role in groupthink and homogenous news coverage. This groupthink attracted renewed criticism after the unexpected victory of Republican candidate Donald Trump in the 2016 US presidential election as the campaign coverage had indicated a likely win by the Democratic candidate Hillary Clinton. This pattern was repeated in the 2017 UK election when the Conservative party lost their majority after a campaign in which the news coverage had pointed to an overall Tory victory. Such groupthink is often attributed to homophily, the tendency of individuals to interact with those most like them, and while homophily in the legacy media system is well-studied, there is little research around homophily in the hybrid media system, even as social media platforms like Twitter facilitate the development-and analysis-of virtual political journalism packs. This study, which compares Twitter interactions among US and UK political reporters in the 2016 and 2017 national elections, shows that political journalists are overwhelmingly more likely to use Twitter to interact with other journalists, particularly political journalists, and that their offline tendencies to form homogenous networks have transferred online. There are some exceptions around factors such as gender, news organizations and types of news organization-and important distinctions between types of interactions-but overall the study provides evidence of sustained homophily as journalists continue to normalize Twitter.
\end{abstract}

\section{Keywords}

elections; groupthink; homophily; political journalism; Twitter, UK; US

\section{Issue}

This article is part of the issue "Journalism and Social Media: Redistribution of Power?", edited by Marcel Broersma and Scott Eldridge II (University of Groningen, The Netherlands).

(C) 2019 by the author; licensee Cogitatio (Lisbon, Portugal). This article is licensed under a Creative Commons Attribution 4.0 International License (CC BY).

\section{Introduction}

The 2016 election of President Donald Trump in the US sent shock waves through the American political and media establishment. There were questions about journalism practice amid the "surprising election outcome" as the generally homogenous news coverage had long painted Clinton as the inevitable winner (Boydstun \& Van Aelst, 2018, p. 672; Watts \& Rothschild, 2017). The same questions arose in Britain some months later as the Conservative party lost their ruling majority to the surprise of much of the political media who were described as falling victim to "confirmation bias" in their reporting
(Enten \& Silver, 2017). Such homogenous reporting is a hallmark of "pack journalism" where political journalists are more likely to aim for unanimity than dissent in their work processes and in doing so build echo chambers or filter bubbles, albeit unwittingly, by quoting from the same sources and focusing on the same issues and profoundly shaping news coverage as a result (Matusitz \& Breen, 2012; Mourão, 2015; Usher, Holcomb, \& Littman, 2018). Homophily, which describes the tendency of likeminded individuals to "flock together" around shared status or values (McPherson, Smith-Lovin, \& Cook, 2001) can be seen as the cornerstone of such echo chambers as these groups of most-similar individuals build sustained 
and persistent connections with those who most reflect their views, sharing and re-sharing similar information almost to the point of redundancy (Himelboim, Sweetser, Tinkham, Cameron, Danelo, \& West, 2016). However, while pack journalism is well studied in the legacy media system, homophily or "virtual pack journalism," has not received the same attention (Kiernan, 2014) and, perhaps, more importantly, while several studies have explored social media homophily among individuals, there is a lack of research into social media homophily among elite groups such as political journalists, despite journalism's critical role in setting the news agenda (Wihbey, 2018). This study focuses on Twitter as it is widely considered the most important digital communication technology for journalists and "absolutely integral" to political journalists' work in the US and UK (Hanusch, 2018; Kreiss \& McGregor, 2018, p. 326; Usher et al., 2018). The platform plays a key role in influencing journalists' news judgment (McGregor \& Molyneux, 2018) and is so dominant in political journalism (Parmelee, 2013) that journalists' interactions there can be expected to affect news coverage and, by extension, the public agenda (Chadwick, 2013).

While the UK and US have been well studied individually in the past, a comparative study is instructive in this context as both countries, two of the largest journalism markets in the world, share enough similarities in their political and media systems to help limit uncontrollable variables (Deuze, 2002; Hallin \& Mancini, 2004). This type of "most-similar-systems" design (Przeworski \& Teune, 1970) is particularly useful in helping to identify shared characteristics or similar patterns around journalism interactions and can highlight the development, if any, of a nascent political journalism culture on Twitter, particularly around elections. As Hallin and Mancini noted in 2004, there are key differences between the two countries with public service broadcasting seen as much stronger in the UK than the US; and political neutrality stronger in all sectors except the UK newspaper segment; although, as the authors wrote in 2004, there were already clear signs of change in the US broadcasting segment with the then nine-year-old Fox News TV seen adopting "a distinctive, rightward tilt." Overall however, there is enough strength in the US and UK political and cultural ties, particularly around professionalism and styles of journalism, to create more similarities than differences, and the resulting comparisons provide a useful lens into drafting a framework of commonalities and contrasts around political journalists' Twitter activity during election campaigns in two major Western democracies. Election reporting is a special case in journalism studies because political journalists work under specific regulatory environments and are reporting on politicians and parties who are intensely active, and with a public that pays more attention to how politics is presented (Van Aelst \& De Swert, 2009). While this may be rather narrow it does mean that a focus on this particular period increases the comparability of the results not only within this study but outside of it. Indeed, the study of political news and journalists has traditionally focused on election campaign periods (Semetko, 1996) and research has already shown that increased Twitter activity can be expected in the closing weeks of an election offering a rich data seam of interactions for analysis (Enli \& Skogerb $\varnothing$, 2013; Jungherr, 2016; Nuernbergk \& Conrad, 2016).

This study, which is the first comparative analysis to specifically explore homophily within political journalists' Twitter networks during an election campaign, aims to fill the spaces in the literature on political journalists' activity noted by Broersma and Graham (2016) and Nuernbergk (2016). The analysis specifically focuses on retweets and replies as these "mutual discourse" tweets are considered the most interactive forms of engagement and are thus vital to understanding developing journalism practices on Twitter (Bruns \& Burgess, 2012; Parmelee \& Deeley, 2017). The over-arching research question is whether political journalists are using Twitter's potential to make a sustained effort to engage with new and diverse voices or instead using the platform to take cues from each other and generally participate in "water-cooler" conversations and migrate their legacy pack routines online (Kiernan, 2014; Molyneux \& Mourão, 2019, p. 261). This question is explored by the analysis of retweets and replies and most-frequentlytargeted users to determine evidence of homophily and also the impact of potential factors such as gender, news organization and types of news organization. The study begins with an overview of normalization, homophily, Twitter journalism, retweets and replies, and then explores those interactions from a total of 202 UK and US political journalists through a quantitative analysis of the retweets and replies produced in the run-up to the 2016 and 2017 US and UK national elections before turning to the discussion and conclusion.

\section{Literature Review}

From the telegraph to typewriters to television to Twitter, successive technological innovations have transformed the norms and practice of journalism (Lasorsa, Lewis, \& Holton, 2012) and each new technology has arrived amid much fanfare about its potential impact on political communication, particularly around election campaigns (Stromer-Galley, 2014). Ultimately however, the expectations and concerns about these potential utopias and dystopias have never been fully realized as the power structures of journalism and politics have instead normalized each new "new media" into their own practice (Singer, 2005). The potential power of digital media in election campaigns was first seen in the US in the 2004 Presidential campaign when it rocketed the relatively unknown candidate Howard Dean into the political and media stratosphere (Stromer-Galley, 2014) but as Margolis and Resnick had already argued in 2000, any of the digital advantages accruing to early adopters like Dean were soon eclipsed as the political and journalism elite folded 
these new technologies into existing practices when they recognized, and thereby normalized, the "new" new media (Margolis \& Resnick, 2000).

Much of the research into Twitter journalism practice argues that journalists, seen as frequent, if not always skillful, Twitter users (Engesser \& Humprecht, 2015) are well down the path of normalization, using Twitter in ways that conform to existing practice rather than using it to change journalism practice (see Lasorsa et al., 2012; Lawrence, Molyneux, Coddington, \& Holton, 2014; Lewis, 2012; Molyneux \& Mourão, 2019; Nuernbergk, 2016; Parmelee, 2013). This is especially evident in areas such as gatekeeping, where journalists have long controlled whose voices make it through the editorial "gates" (Lasorsa et al., 2012; Singer, 2005), and Twitter gatekeeping can be seen in the "insider talk" and "regurgitation" of information flowing across Twitter (Lawrence et al., 2014; Parmelee, Roman, Beasley, \& Perkins, 2019, p. 161) as journalists more frequently engage with other journalists or newsmakers-and even themselves-rather than interest groups, academics or citizens (Carlson, 2017; Molyneux \& Mourão, 2019). While journalists can, and do, challenge normalization in other areas of journalism practice (see Broersma \& Graham 2016; Molyneux \& Mourão, 2019), this study's sole concern is whether political journalists create homogenous packs on Twitter, thus supporting the idea of homophily, and by extension, normalization, even as the hybrid media system (Chadwick, 2013) theoretically presents alternatives to the pack model with a wider range of interaction partners and voices outside the bubbles. While some studies indicate more negotiation around normalization in newer affordances such as quote tweets or areas such as monitoring, sourcing, publishing, promoting and branding (Broersma \& Graham, 2016; Molyneux \& Mourão, 2019; Tandoc \& Vos, 2016), the research overwhelmingly indicates that journalists' interactions are dominated by other journalists and that these homogenous online networks resemble those built by journalists offline (Hanusch \& Nölleke, 2018).

However, despite the plethora of studies indicating that journalists' Twitter networks are so homogenous as to suggest homophily there has been little research so far specifically into homophily in those interactions even as journalists themselves report low levels of citizen engagement. For example, Gulyas (2017) found journalist/citizen interaction at 23 and 27 percent in the US and UK respectively, and Nuernbergk (2016) saw only rare interactions between German journalists and their Twitter followers, thus suggesting that political journalists still prefer to connect with each other in "journalism-centered bubbles" (Molyneux \& Mourão, 2019; Mourão, 2015; Nuernbergk, 2016, p. 877). Additionally, researchers have noted evidence of bubbles within bubbles (Bentivegna \& Marchetti, 2018) with political journalists seen as more likely to interact with other political journalists (Hanusch \& Nölleke, 2018); selfsegregating by gender (Artwick, 2013; Usher et al., 2018), and focusing on those inside their own news organization (Bentivegna \& Marchetti, 2018; Larsson, Kalsnes, \& Christensen, 2017) with Vergeer (2015) reporting that regional reporters were more likely to do this than national journalists. While these studies were broad in nature, Hanusch and Nölleke (2018) specifically considered the potential impact of beat, gender, organizational context and geographic proximity in an extensive inquiry into homophily among Australian reporters and found a high degree of homophily across those four shared characteristics.

Homophily, or the tendency of individuals to form groups with those most similar to themselves (McPherson et al., 2001) was introduced as a concept in the 1950s when Lazarsfeld and Merton (1954) proposed that individuals were far more likely to build networks around shared values in areas like religion or sport or around shared status in areas such as race, ethnicity, sex, age, religion, education and occupation (Hanusch \& Nölleke, 2018; McPherson et al., 2001). As an elite specialty within the wider occupational field of journalism, political journalists are perhaps more sensitive to the homophilous effects of these tight-knit groups as they seek validation from "those to whom we compare ourselves, those whose opinions we attend to, and simply those whom we are aware of and watch for signals about what is happening in our environment" (McPherson et al., 2001, p. 428). The tendency for political reporters to focus on each other was first labelled as "pack journalism" during the 1972 US presidential election when Rolling Stone reporter Tim Crouse noted that the journalists' intent focus on each other led to a shared groupthink about the day's most important stories and created a pack dynamic so strong that "almost all the reporters will take the same approach to the story", even though they were ostensibly competing against each other (Crouse, 1973). As former Newsweek Bureau Chief Karl Fleming said: "Their (the reporters') abiding interest is making sure that nobody else has got anything that they don't have-not getting something that nobody else has" (Crouse, 1973).

While Crouse observed the political journalism network and the resulting groupthink from his physical seat on the campaign bus, researchers can now observe virtual political journalism networks from afar through the analysis of publicly-visible Twitter conversations and the use of affordances such as retweets, replies, mentions and followings. Retweet and mention networks (which include both replies and indirect mentions) are often seen as the strongest interaction markers (Hanusch \& Nölleke, 2018) and several studies have reported differences in the way journalists use retweets and mentions with more homophily seen in mentions than retweets (Hanusch \& Nölleke 2018; Molyneux \& Mourão, 2019; Nuernbergk, 2016). However, indirect mentions can be also be used as a "shout out" (Usher et al., 2018) thus diluting their effectiveness as a distinct measure of interactive intent. Retweets, despite 
multiple Twitter disclaimers to the contrary (Hanusch \& Nölleke, 2018), are most often viewed as an endorsement of content (Meraz \& Papacharissi, 2013; Russell, Hendricks, Choi, \& Stephens, 2015), but they also convey endorsement of the user and the link between the original and retweeting sender provides evidence of a pre-existing homophilous network of like-minded people (Bruns \& Burgess, 2012; Hanusch \& Nölleke, 2018). While some journalists use replies to thread longer posts together and circumvent Twitter's 280-character count (Molyneux \& Mourão, 2019, p. 257), specific replies (as against indirect mentions) are more typically interactive with some research indicating potential heterophily with studies showing "public/citizen" users receiving as high as 48 percent of the journalists' replies (Brems, Temmerman, Graham, \& Broersma, 2017). However, these studies don't mention if the accounts received more than one reply which would help us consider the nature and value of such interactions, a problem noted by Parmelee and Deeley in 2017, when they queried the use of simple counts arguing that such one-offs were inadequate ways to measure reciprocity. Such reciprocity is often absent in followings (Kiousis, 2002) and, as Ausserhoffer and Maireder reported in 2013, followings are not a reliable metric as they can be paid for or artificially enhanced by computer scripts. Subsequently, this study views the affordances of retweets and replies as more indicative of actual intent, highlighting the user's value to the journalist (Conover et al., 2011; Molyneux, 2015).

Frequency of interactions is also important. As McPherson et al. (2001) outlined, homophily can be seen in those whose "opinions we attend to" and given the concerns raised by Parmelee and Deeley (2017) around one-off replies, this study measures interactivity by focusing on the political journalists' most-frequent discussion partners in replies and retweets to see which voices the journalists most frequently attend to. This research builds on the developing work into Twitter journalism homophily (see particularly Hanusch \& Nölleke, 2018) and is important as it is the first to examine this issue in the context of social media election coverage, specifically on Twitter, and takes the analysis further by looking at media practice in two similar media systems. The importance of studies such as this, which examine these "new" types of interactions on social media, cannot be overstated as the work done by political journalists remains essential to a citizen's ability to understand politics and election campaigns even in a digital and networked age (Harder, Paulussen, \& Van Aelst, 2016; Kuhn \& Nielsen, 2014).

\section{Research Questions}

This study explores retweets and replies as two distinct affordances and explores them separately for the presence of homophily by asking the following two research questions:
RQ1: To what extent can homophily be identified in political journalists' retweets on Twitter in an election campaign?

RQ2: To what extent can homophily be identified in political journalists' replies on Twitter in an election campaign?

Drawing from the categories devised in Hanusch and Nölleke's study (2018) the study then considers if organizational context, types of news organization or gender can be seen to play a role in homophily in political journalists' retweets and replies, which leads to these research questions:

RQ3: Do shared characteristics such as news organizations; type of news organizations and gender play a role in homophily in retweets?

RQ4: Do shared characteristics such as news organizations; type of news organizations and gender play a role in homophily in replies?

\section{Data and Methods}

The research questions are examined by comparative analysis of replies and retweets from a sample of some 202 political journalists working at the national level in the US and the UK. The data for this study were retrieved from a 2015 list of 183 UK Parliamentary Lobby Correspondents with Twitter accounts (Hanusch, 2018) which was filtered to focus on national political reporters and those who tweeted more than once a day. Unlike previous studies (see Lasorsa et al., 2012; Usher et al., 2018; Singer, 2005) this sample excluded commentators and columnists as their work is significantly different to that of political reporters (Rogstad, 2014). This UK list was then used to create a cross-national comparable sample of US political journalists by using Twitter's search function to identify people who publicly represented themselves as journalists by searching for keywords (such as "politics", "political", "politic"*, "correspondent", "campaign", "reporter", "journalist", etc.) in the user's profile and then cross-referencing those names against lists from the US White House Correspondents Association; the US Congressional Press Galleries; campaign embeds at the TV networks and media lists maintained by the US public relations firm Cision. This resulted in a list of 54 male and 43 female reporters from 26 outlets in the US and 75 male and 30 female reporters from 29 outlets in the UK (see Table 1).

The data were collected during the two weeks prior to each national election (October 22 to November 8, 2016 in the US; and May 22 to June 8, 2017 in the UK) and while content analysis is beyond the scope of this study, this period was chosen as it is the time when media coverage of elections can be expected to be intense (Van Aelst \& De Swert, 2009). The tweets were collected on the cloud-based Discover Text Twitter archive service which returned 100 percent of the users' tweets. This 
Table 1. US and UK news outlets in study.

\section{US News Outlets}

\begin{tabular}{|c|c|c|c|}
\hline Broadcast & Digital & Print & Wire \\
\hline$A B C$ & Bloomberg & Boston Globe & $\mathrm{AP}$ \\
\hline CBS & Daily Beast & LA Times & Reuters \\
\hline CNN & DC Examiner & National Review & \\
\hline Fox & Fusion & New York Daily News & \\
\hline NBC & Politico & The New York Times & \\
\hline \multirow[t]{5}{*}{ NPR } & The Hill & USA Today & \\
\hline & The IJR & Washington Post & \\
\hline & Vox & Wall Street Journal & \\
\hline & Wired & & \\
\hline & Yahoo News & & \\
\hline \multicolumn{4}{|c|}{ UK News Outlets } \\
\hline Broadcast & Digital & Print & Wire \\
\hline $\mathrm{BBC}$ & Business Insider & Daily Express & AP \\
\hline Channel 4 & Bloomberg & Daily Mail & PA \\
\hline ITV & BuzzFeed & Daily Mirror & Reuters \\
\hline \multirow{9}{*}{ Sky } & Huffington Post & Daily Telegraph & \\
\hline & inews & Evening Standard & \\
\hline & PA & Financial Times & \\
\hline & Parly & The Guardian & \\
\hline & Politico & The Independent & \\
\hline & Politics.co.uk & The Sun & \\
\hline & The Independent & The Times & \\
\hline & The Spoon & & \\
\hline & Total Politics & & \\
\hline
\end{tabular}

search resulted in some 26,820 tweets from the US journalists and 30,992 tweets from the UK journalists which were then queried for reply and retweet users. The metadata provided by Discover Text included "retweet-link" and "reply-to-link" which ensured that the intended object of the reply or retweet was accurately retrieved even if the tweet featured one or more @mentions. This data formed four distinct user sets comprising total replies and retweets as follows:

US: 3,333 unique users in 12,562 retweets and 1,595 unique users in 2,919 replies.

UK: 3,556 unique users in 13,747 retweets and 3,104 users in 6,764 replies.

To better answer the questions about sustained interactivity, the data were then queried for the median number of times unique users featured in either a retweet or a reply to exclude any single retweets or replies. The query returned a median of 1 for retweets and replies for both countries' data which showed that at least half the users were of weak or limited value. This early finding supported the decision to focus only on the most prevalent users and to do so, this article adopted Meraz's "power law" (2009) which holds that the top 10 to 20 percent of users will attract the majority of attention, to identify the most-frequently-mentioned users. The unit of analy- sis was the individual user and the four sets of data were then queried separately to locate the top 10 percent of accounts mentioned. These data sets were coded manually by the author according to the following categories using information from the user's Twitter profile and following Hanusch and Bruns (2017) the outlets were coded as broadcast (commercial, public, TV and radio), print, wire service, digital or freelance.

User type: political journalist; other journalist; news outlet or other user.

Gender: male or female (where applicable).

News organization: from user's Twitter biography profile. Type of news organization: broadcast, print, wire or digital.

Later, the senders and users were labelled as same-tosame or same-to-different by gender, news organization and type of news organization. The coding for the mentioned users was primarily drawn from their Twitter biography profiles, where journalists typically identify their occupation and news organization (Ottovordemgentschenfelde, 2017), and this information was saved as a static record by Discover Text at the same time as the data collection. When the bio information was absent from the downloaded data (as in the case of quote retweets which comprised about 10 percent of the over- 
all data), a careful Google search was implemented for both user and workplace information at the time of the relevant election. This two-pronged archiving method helped build a single static set of data and thus avoided the methodological issues associated with collating data from online profiles which, as Lewis et al. noted in 2013 (p. 45), are inherently malleable. The profile information was coded by the author, while another coder examined a total of 114 profiles of those mentioned in retweets and replies (10 percent) to test the validity of the data. Using Krippendorff's alpha test (Freelon, 2010) for nominal coding, the reliability was rated excellent with 0.85 for type of journalist; 0.95 for gender; 0.92 for news organization and 0.83 for type of news organization.

To answer RQ1 and RQ2 the article looks at the types of users in the retweets and replies as group-level percentages to identify the main discussion partners. To answer RQ3 and RQ4 the article looks at the political journalists' mean rates of interaction in retweets and replies with the other political journalists identified in the study and compares this data by news organization, type of news organization and gender across the two countries using Cohen's $d$ to measure for effects. The results are presented below.

\section{Results}

\subsection{RQ1: Homophily in Retweets}

RQ1 investigated the presence of homophily in retweets in the US and the UK. Taking the US first, the power law showed that the top 10 percent of the unique 3,333 names, or 333 users, were responsible for 63 percent of the retweets or 7,859 of the 12,562 retweets. This pattern was almost identically repeated in the UK. There, the top 10 percent of the 3,556 unique names, or 356 accounts, were responsible for 62 percent of the retweets or 8,573 of the 13,747 retweets. The two sets of the top 10 percent of frequently-named users in retweets $(7,859$ in the US and 8,573 in the UK) form the retweet network dataset.

As can be seen in Figure 1 political journalists and political news media accounts comprised the largest group of retweets in both countries accounting for a total of 82 percent of the US sample $(6,438$ out of the 7,859 retweets) and 64 percent of the UK sample $(5,487$ of the 8,753 retweets). Altogether, journalists or news organizations comprised the majority of retweeted actors in both countries with 7,343 of the 7,859 retweets (93 percent) in the US and 7,179 of the 8,573 retweets ( 84 percent) in the UK. Some differences were immediately obvious as the UK political journalists retweeted a much higher percentage of non-journalists with 16 percent against 7 percent in the US.

The findings point to a large degree of homophily in political journalists' retweet networks in both the US and the UK with a greater focus on US political journalists in the US than the UK.

\subsection{RQ2: Homophily in Replies}

RQ2 investigated the presence of homophily in replies in the US and the UK. The power law for the US showed

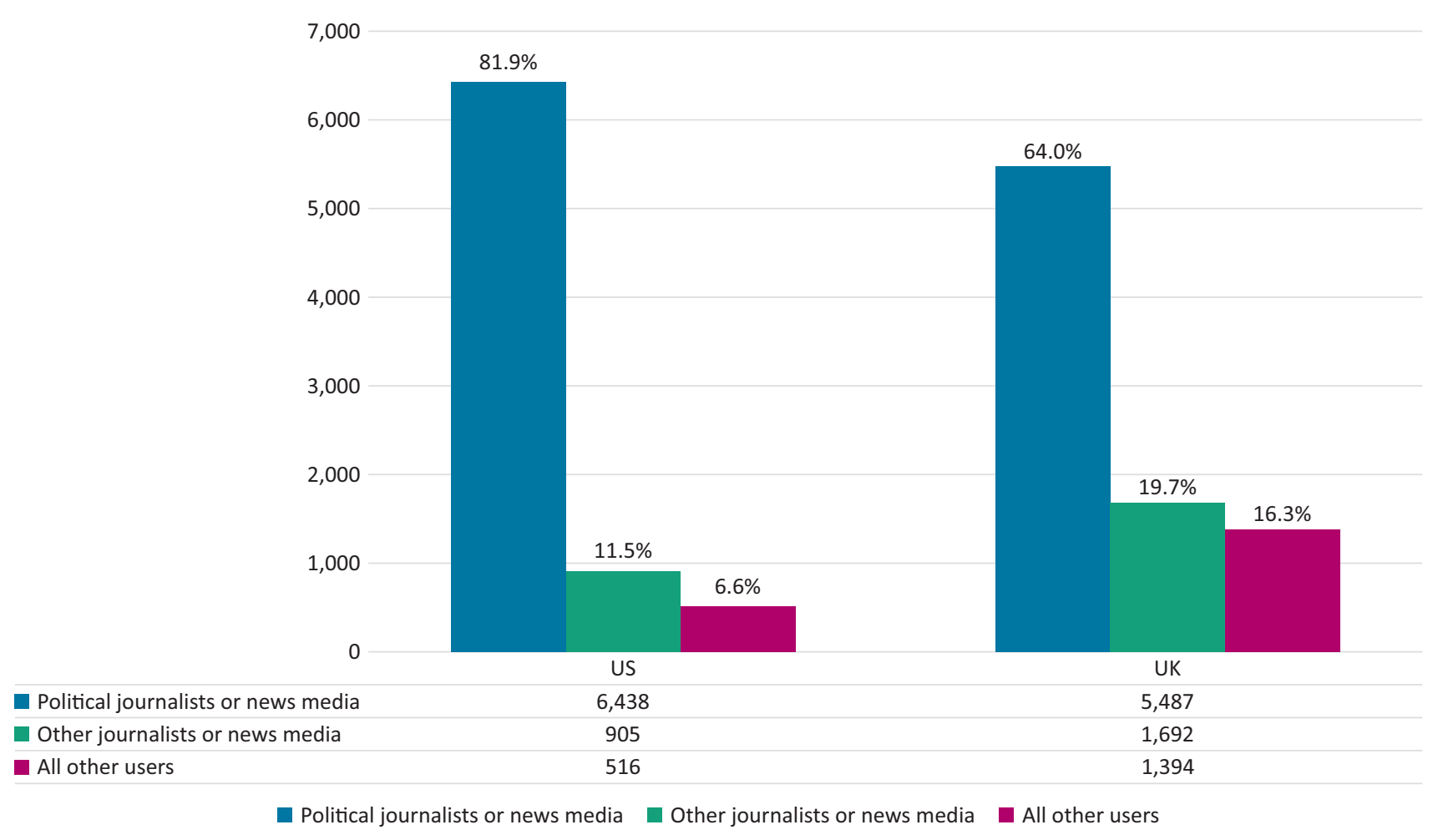

Figure 1. Political journalists' preferred discussion partners in retweets. 
that the top 10 percent of the unique 1,595 names, or 159 users, were responsible for 42 percent of the replies, or 1,236 of the 2,919 replies. The power law for the UK showed that the top 10 percent, or 310 users, received 48 percent of the replies, or 3,283 replies of the 6,764 replies. These two sets of the top 10 percent of most frequently-named reply-to users $(1,236$ in the US and 3,283 in the UK) form the reply network dataset.

The findings show that the UK political journalists used replies far more frequently than the US indicating some differences in overall behavior patterns, but while the use of replies was far higher in the UK, the focus on political journalists is again consistent as can be seen in Figure 2 with both close to 70 percent. Overall, journalists comprised the largest group of users with 1,032 of the 1,236 replies ( 83.5 percent) in the US and 2,557 of the 3,283 replies (78 percent) in the UK. Unlike the retweet activity, all replies were sent to individual users and were never used to interact with news organizations or branded accounts. Also, both UK and US journalists included a wider range of non-journalist voices in replies than retweets with 22 percent in the UK and 16.5 percent in the US.

The findings point to a far greater usage of the reply function in the UK and a significant degree of homophily in political journalists' reply networks in both countries. The weaker power law in both countries suggests that the political reporters replied to a far larger number of people-which is indicative of homophilybut given the overall median (1), the findings could also suggest that the majority of replies were probably the one-off comments or thank-yous noted by Parmelee and Deeley (2017).

\subsection{RQ3: Shared Characteristics in Retweets}

The findings in RQ1 established the presence of homophily among political journalists in retweet networks and this section specifically looks at the interactions identified as political-journalist-to-political-journalist to consider if the criteria of news organization, types of news organization or gender can be seen to play a role. This question is explored through paired samples t-tests with effect sizes calculated using Cohen's $d$ (Hanusch \& Nölleke, 2018). In relation to the first criterion of news organization, the results show remarkably consistent patterns of behavior with both the UK and US journalists more likely to retweet outside their organization with the paired sample t-tests showing reasonably similar smallto-medium sized effects as can be seen in Table 2. Looking at types of news organizations, print and broadcast journalists in both countries are more likely to retweet within their own sectors with the results showing quite large effects, specifically in the US broadcast and UK newspaper segments. The results are more mixed in the newer digital sector with US journalists displaying more heterophily and UK journalists more homophily with the effect size small. The results for wire journalists again suggest US heterophily and UK homophily although with large effect size in the US and small effect in the UK. Turning to gender, the results (see Table 2) show that both US and UK male political reporters are far more likely to interact with other male political journalists with a large effect seen in both countries. In comparison, female political journalists are more likely to retweet male political journalists in both the US and the UK with a larger effect seen in the US pointing to homophily in the male

2,500

$68.1 \%$

2,000

1,500

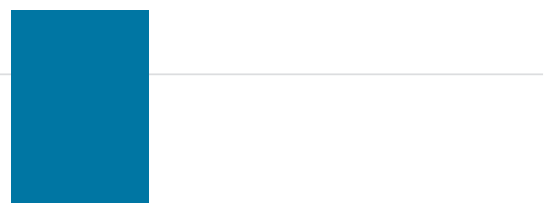

1,000

500

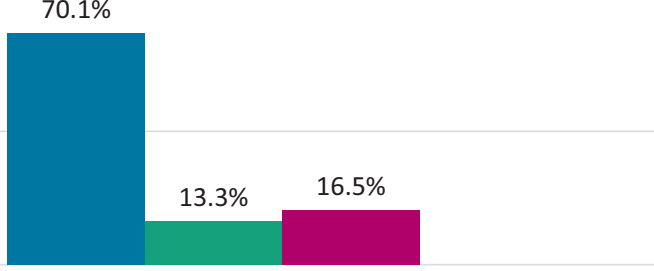

0

US

Political journalists

867

165

Other journalists

- All other users

204

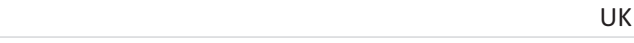

2,236

321

726

Political journalists Other journalists All other users

Figure 2. Political journalists' preferred discussion partners in replies. 
Table 2. Shared characteristics in retweets.

\begin{tabular}{|c|c|c|c|c|c|c|c|c|c|c|}
\hline \multirow{3}{*}{ Characteristics } & \multicolumn{10}{|c|}{ Retweets } \\
\hline & \multicolumn{5}{|c|}{ US political journalists } & \multicolumn{5}{|c|}{ UK political journalists } \\
\hline & $N$ & $\begin{array}{c}\text { Same } \\
M^{*}(S D)\end{array}$ & $\begin{array}{c}\text { Other } \\
\mathrm{M}^{*}(\mathrm{SD})\end{array}$ & Sig & $\begin{array}{c}\text { Cohen's } \\
d\end{array}$ & $N$ & $\begin{array}{c}\text { Same } \\
\mathrm{M}^{*}(\mathrm{SD})\end{array}$ & $\begin{array}{c}\text { Other } \\
\mathrm{M}^{*}(\mathrm{SD})\end{array}$ & Sig & $\begin{array}{c}\text { Cohen's } \\
d\end{array}$ \\
\hline News organization & 6,438 & $26(31)$ & $40(48)$ & $* * *$ & 0.35 & 5,487 & $21(42)$ & $32(49)$ & $* * *$ & 0.24 \\
\hline \multicolumn{11}{|c|}{ News organization type } \\
\hline Print & 2,662 & $39(45)$ & $37(45)$ & $* * *$ & -0.04 & 2,112 & $33(43)$ & $18(23)$ & $* * *$ & -0.44 \\
\hline Broadcast & 2,106 & $51(49)$ & $22(27)$ & $* * *$ & -0.73 & 1,299 & $20(27)$ & $16(35)$ & $* * *$ & -0.13 \\
\hline Digital & 1,078 & $23(30)$ & $28(39)$ & $* * *$ & 0.14 & 2,034 & $52(90)$ & $40(51)$ & $* * *$ & -0.16 \\
\hline Wire & 592 & $17(8)$ & $32(28)$ & $* * *$ & 0.73 & 42 & 7 (10) & $4(6)$ & $* * *$ & -0.36 \\
\hline Overall & 6,438 & $36(42)$ & $30(37)$ & $* * *$ & -0.15 & 5,487 & $31(53)$ & $21(36)$ & $* * *$ & -0.22 \\
\hline \multicolumn{11}{|l|}{ Gender** } \\
\hline Female & 2,243 & $21(26)$ & $31(40)$ & $* * *$ & 0.30 & 884 & $8(11)$ & $23(29)$ & $* * *$ & 0.68 \\
\hline Male & 3,789 & $51(59)$ & $20(21)$ & $* * *$ & -0.70 & 4,132 & $48(75)$ & $9(12)$ & $* * *$ & -0.73 \\
\hline Overall & 6,032 & 38 (49) & $25(31)$ & $* * *$ & -0.32 & 5,016 & $37(66)$ & $13(20)$ & $* * *$ & -0.49 \\
\hline
\end{tabular}

Note: $\mathrm{M}^{*}(\mathrm{SD})=$ mean and standard deviations. ${ }^{* *}$ These data include only journalist-to-journalist interactions.

networks and heterophily in the female networks. Comparing countries, the sectors most likely to see the most significant homophily are UK newspapers; US broadcasters; US and UK male reporters and UK female political reporters with US wire reporters and UK female journalists likely to see the most significant heterophily.

\subsection{RQ4: Shared Characteristics in Replies}

This section specifically looks at the replies identified as political-journalist-to-political-journalist in RQ2 to consider the impact of the same shared characteristics discussed above. While the findings around retweets in RQ3 were mixed, the evidence on replies is more clear-cut with more homophily than heterophily evident across the shared characteristics in the two countries as can be seen in Table 3. In relation to the first criteria of news organization, the results again showed similar activity by US and UK journalists although this time they were both seen as more likely to reply to colleagues within their own organization, with a larger effect size in the US. Looking at types of news organization, the results showed homophily was more likely in nearly all the sectors studied with just US wire reporters showing any evidence of heterophily, although the number of replies was extremely low. While the paired sample t-tests show small

Table 3. Shared characteristics in replies.

\begin{tabular}{|c|c|c|c|c|c|c|c|c|c|c|}
\hline \multirow{3}{*}{ Characteristics } & \multicolumn{10}{|c|}{ Replies } \\
\hline & \multicolumn{5}{|c|}{ US political journalists } & \multicolumn{5}{|c|}{ UK political journalists } \\
\hline & $N$ & $\begin{array}{c}\text { Same } \\
\mathrm{M}^{*}(\mathrm{SD})\end{array}$ & $\begin{array}{c}\text { Other } \\
M^{*}(S D)\end{array}$ & Sig & $\begin{array}{c}\text { Cohen's } \\
d\end{array}$ & $N$ & $\begin{array}{c}\text { Same } \\
\mathrm{M}^{*}(\mathrm{SD})\end{array}$ & $\begin{array}{c}\text { Other } \\
\mathrm{M}^{*}(\mathrm{SD})\end{array}$ & Sig & $\begin{array}{c}\text { Cohen's } \\
d\end{array}$ \\
\hline News organization** & 867 & $12(24)$ & $5(7)$ & $* * *$ & -0.40 & 2,235 & $16(38)$ & $11(19)$ & $* * *$ & -0.17 \\
\hline \multicolumn{11}{|l|}{ News organization type } \\
\hline Print & 271 & $9(16)$ & $3(4)$ & $* * *$ & -0.51 & 703 & $12(17)$ & $7(12)$ & $* * *$ & -0.34 \\
\hline Broadcast & 306 & $17(34)$ & $2(3)$ & $* * *$ & -0.62 & 351 & $15(40)$ & $3(3)$ & $* * *$ & -0.42 \\
\hline Digital & 275 & $21(25)$ & $4(4)$ & $* * *$ & -0.95 & 1,156 & $40(65)$ & $12(16)$ & $* * *$ & -0.59 \\
\hline Wire & 15 & $2(1)$ & $3(1)$ & $* * *$ & 1.00 & 25 & $3(5)$ & $3(4)$ & $* * *$ & 0.00 \\
\hline Overall & 867 & $14(24)$ & $3(3)$ & $* * *$ & -0.64 & 2,235 & $20(41)$ & $7(12)$ & $* * *$ & -0.43 \\
\hline \multicolumn{11}{|l|}{ Gender** } \\
\hline Female & 154 & $6(10)$ & $2(3)$ & $* * *$ & -0.54 & 469 & $13(35)$ & $8(20)$ & $* * *$ & -0.18 \\
\hline Male & 713 & $20(30)$ & $2(2)$ & $* * *$ & -0.85 & 1,766 & $26(46)$ & $2(4)$ & $* * *$ & -0.74 \\
\hline Overall & 867 & $15(26)$ & $2(2)$ & $* * *$ & -0.71 & 2,235 & $23(43)$ & $4(11)$ & $* * *$ & -0.61 \\
\hline
\end{tabular}

Note: $\mathrm{M}^{*}(\mathrm{SD})=$ mean and standard deviations. ${ }^{* *}$ These data include only journalist-to-journalist interactions. 
to medium-sized effects across types of sector, significant differences could be seen in the US digital, and to a lesser extent, the US broadcast sectors. In gender, the tendency towards homophily is more obvious than in the retweet networks with both genders seen as more likely to reply to their own gender with a larger effect seen for male reporters in both countries.

\section{Discussion}

The results of this study point to significant homophily throughout political journalists' interaction networks during the US and UK election campaigns, offering key insights into the emergence of common Twitter practices among political journalists in two of the "Liberal Media" countries (Hallin \& Mancini, 2004); and providing further evidence of the continuing normalization of Twitter in the hybrid media environment. The results show that political journalists in both the US and the UK are significantly more likely to engage with other political journalists during election campaigns and that the extent of such homophily can be affected by factors like news organization, types of news organization (print; broadcast; digital or wire) and gender. However, while the findings point to overall homophily there are some marked differences between the two countries and between the two types of interactions as discussed below.

To answer the first two research questions, the study shows a pronounced degree of homophily in both countries in retweets and replies with higher rates of homophily in retweets. While the US journalists are more likely to be more homophilous overall, the political reporters in both countries formed distinct journalismcentered bubbles-with political journalists the single largest group-and "other" non-journalism voices significantly marginalized. Taking retweets first, the US political journalists paid more attention to other political reporters than their UK counterparts with 82 percent against 64 percent. However, the political reporters in both countries retweeted very high percentages of journalists overall with 93 percent in the US and 84 percent in the UK. The difference in types of journalists and the higher UK retweeting rates of non-journalist accounts (16 percent to 7 percent in the US) could be attributed to the suicide bombing in Manchester during the UK election campaign which caused 23 deaths and led to the 24-hour suspension of the campaign. While content analysis was beyond the scope of this article, examining the content of the retweets would help in determining if the difference around retweeted users could be explained by the effect of this major news story which dominated the news cycles for days in the UK. The findings on replies may also have been impacted by the May 22 suicide attack. The percentage of political-journalist-to-politicaljournalists replies in both countries were roughly similar (US: 70 percent; UK: 68 percent) which suggests some significant similarities in the cross-national trend, but there were also quite marked differences: UK reporters sent more than three times the number of replies than the US reporters and the higher number of replies were used to engage with a higher percentage of non-journalists with 22 percent against 16.5 percent in the US. Again, content analysis would be useful in understanding if the differences are linked to a major news story that disrupted the UK election campaign rather than emerging differences in journalism practice in two similar media systems.

The second two research questions explored the degree of homophily in retweets and replies across a set of shared characteristics and found that news organization, types of news organization (print, broadcast, digital or wire) and gender play a role in the homophily observed in both countries. The study shows similar patterns in both countries, particularly around gender, with significant levels of homophily in male political journalists' interactions. While both male and female journalists are more likely to use replies to interact with their own gender; the effects are small to medium-sized for females and more pronounced for males. The impact of gender in retweets is striking with both male and female political journalists in the UK and US more likely to retweet male political journalists than female political journalists. However, given that the amplification most often benefits male political journalists, the gender findings, while initially suggestive of homophily, may in fact be more reflective of the political journalism gender inequities highlighted by Usher et al. in 2018. Indeed, the findings here almost exactly mirror those from Hanusch and Nölleke (2018) whose work on Australian reporters found only mild gender-based heterophily within female retweet networks. The lack of gender diversity among political journalists, particularly in the UK parliamentary press lobby, has been highlighted in recent years (Tobitt, 2018) and these findings suggest that male political journalists' voices are amplified by Twitter journalism engagement practices in both countries.

Interestingly, the analysis of news organizations showed political journalists in both countries were more likely to retweet political journalists from outside their organizations than inside, echoing Vergeer's 2015 finding that Dutch national news journalists were more likely to connect with those outside their own news organizations. While news organization was not seen as a major factor in Twitter homophily, types of news organization did emerge as a significant factor, in particular the US broadcast sector and the UK newspaper sector, findings which may point to a linkage between political bias and Twitter homophily as these are the two media sectors generally regarded as more politically biased than other types of news organizations in their respective countries (Hallin \& Mancini, 2004).

Overall, homophily is clearly visible in the political journalists' sustained Twitter interactions as they repeatedly train their attention on other political journalists in retweets and replies and re-create their legacy pack networks online. While homophily itself does not become more, or less, apparent during election campaigns, these 
time-frames were chosen to explore the most frequent discussion partners chosen by political journalists during a period when the public is paying more attention to politics and to explore how journalists sort themselves into the kinds of homophilous groups, or filter bubbles, which can amplify the general consensus and shape the types of news that develop (Carlson, 2017). Much is known about homophily in legacy journalism practice but research into similar behavior on Twitter has been slow to emerge, even as studies have frequently pointed to high rates of journalist-to-journalist interactions on Twitter.

The very speed with which journalists have adopted Twitter and integrated it into their work routines may have helped create the kinds of homophilous macro processes revealed in this study, processes which are difficult to detect or prevent at the individual journalist level (Vergeer, 2015). Studies such as this can perhaps help educators and newsrooms alike in creating more education and awareness around engagement and interaction on platforms like Twitter, which offer a myriad of opportunities for journalists to interact with other information sources, and thus avoiding the intra-journalistic activity and pack journalism identified here.

The significant differences in gender warrant more research. It is beyond the scope of this article to determine whether or not the political journalists were deliberately or inadvertently focusing on male political journalists, but these interaction patterns deserve greater inquiry and the findings again speak to the pressing need for increased education around diversity in Twitter interactions.

Finally, while concerns have been raised around the propensity of citizens to receive information via filter bubbles on social media, the results of this study suggest that perhaps more attention should be focused on journalists rather than individuals as a journalist's filter bubble can have a far more powerful effect on the news agenda. This tendency of political journalists to form close-knit networks on Twitter is particularly worthy of scrutiny as political journalists are essential in explaining campaign policies and platforms and helping voters understand the issues under discussion. Moreover, the power to set the agenda remains concentrated with actors who "enjoy power and visibility both on and off Twitter," (Siapera, Boudourides, Lenis, \& Suiter, 2018) and this study shows that political journalists, despite the almost limitless opportunities to do otherwise, continue to confer such power and visibility on other political journalists, particularly male political journalists, as they remain tethered, albeit virtually, to the journalism packs of the legacy media era.

\subsection{Limitations}

While the results show that US and UK political journalists restrict the range and diversity of voices chosen as discussion partners, there are limitations to this study. For example, while the journalists generated a sizeable number of tweets the population size itself was kept rel- atively small to allow for manual coding and analysis. A larger population size could have explored these issues in more detail, but this would have entailed more coders and/or machine analysis. Content analysis would have helped in exploring some of the issues, particularly the cross-national difference observed in replies.

\section{Acknowledgments}

The author wishes to thank Dr Krishnan Pillaipakkamnatt at Hofstra University and Dr Jane Suiter at Dublin City University for their help and support during this project.

\section{Conflicts of Interest}

The author declares no conflicts of interest.

\section{References}

Artwick, C. G. (2013). News sourcing and gender on Twitter. Journalism, 15(8), 1111-1157. doi:10.1177/ 1464884913505030

Ausserhofer, J., \& Maireder, A. (2013). National politics on Twitter. Information, Communication \& Society, 16(3), 291-314. doi:10.1080/1369118X.2012. 756050

Bentivegna, S., \& Marchetti, R. (2018). Journalists at a crossroads: Are traditional norms and practices challenged by Twitter? Journalism, 19(2), 270-290. doi:10.1177/1464884917716594

Boydstun, A. E., \& Van Aelst, P. (2018). New rules for an old game? How the 2016 US election caught the press off guard. Mass Communication and Society, 21(6), 671-696. doi:10.1080/15205436.2018.1492727

Brems, C., Temmerman, M., Graham, T., \& Broersma, M. (2017). Personal branding on Twitter. Digital Journalism, 5(4), 443-459. doi:10.1080/21670811.2016. 1176534

Broersma, M., \& Graham, T. (2016). Tipping the balance of power. In A. Bruns, G. Enli, E. Skogerb $\varnothing$, A. O. Larsson, \& C. Christensen (Eds.), The Routledge companion to social media and politics (pp. 89-103). New York, NY: Routledge. doi:10.4324/9781315716299

Bruns, A., \& Burgess, J. (2012). Researching news discussion on Twitter. Journalism Studies, 13(5/6), 801-814. doi:10.1080/1461670X.2012.664428

Carlson, M. (2017). Journalistic authority: Legitimating news in the digital era (1st ed.). New York, NY: Columbia University Press.

Chadwick, A. (2013). The hybrid media system: Politics and power (1st ed.). Oxford: Oxford University Press.

Conover, M., Ratkiewicz, J., Francisco, M. R., Goncalves, B., Menczer, F., \& Flammini, A. (2011). Political polarization on Twitter. In Proceedings of the fifth international AAAl conference on weblogs and social media (pp. 89-96). Barcelona, Spain.

Crouse, T. (1973). The boys on the bus. New York, NY: First Ballantine. 
Deuze, M. (2002). National news cultures: A comparison of Dutch, German, British, Australian, and US Journalists. Journalism \& Mass Communication Quarterly, 79(1), 134-149. doi:10.1177/107769900207900110

Engesser, S., \& Humprecht, E. (2015). Frequency or skillfulness. Journalism Studies, 16(4), 513-529. doi:10.1080/1461670X.2014.939849

Enli, G. S., \& Skogerbø, E. (2013). Personalized campaigns in party-centred politics. Information, Communication \& Society, 16(5), 757-774. doi:10.1080/ 1369118X.2013.782330

Enten, H., \& Silver, N. (2017). The U.K. election wasn't that much of a shock. FiveThirtyEight. Retrieved from https://fivethirtyeight.com/features/ukelection-hung-parliament

Freelon, D. G. (2010). ReCal: Intercoder reliability calculation as a web service. International Journal of Internet Science, 5(1), 20-33.

Gulyas, A. (2017). Hybridity and social media adoption by journalists: An international comparison. Digital Journalism, 5(7), 884-902. doi:10.1080/ 21670811.2016.1232170

Hallin, D. C., \& Mancini, P. (2004). Comparing media systems: Three models of media and politics (1st ed.). Cambridge: Cambridge University Press.

Hanusch, F. (2018). Political journalists' corporate and personal identities on Twitter profile pages: A comparative analysis in four Westminster democracies. New Media and Society, 20(4), 1488-1505. doi:10.1177/1461444817698479

Hanusch, F., \& Bruns, A. (2017). Journalistic branding on Twitter. Digital Journalism, 5(1), 26-43. doi:10.1080/ 21670811.2016.1152161

Hanusch, F., \& Nölleke, D. (2018). Journalistic homophily on social media: Exploring journalists' interactions with each other on Twitter. Digital Journalism, 6(7) 1-23. doi:10.1080/21670811.2018.1436977

Harder, R. A., Paulussen, S., \& Van Aelst, P. (2016). Making sense of Twitter buzz. Digital Journalism, 4(7), 933-943. doi:10.1080/21670811.2016.1160790

Himelboim, I., Sweetser, K. D., Tinkham, S. F., Cameron, K., Danelo, M., \& West, K. (2016). Valence-based homophily on Twitter: Network analysis of emotions and political talk in the 2012 presidential election. New Media and Society, 18(7), 1382-1400. doi:10.1177/1461444814555096

Jungherr, A. (2016). Twitter use in election campaigns: A systematic literature review. Journal of Information Technology \& Politics, 13(1), 72-91. doi:10.1080/19331681.2015.1132401

Kiernan, V. (2014). Medical reporters say 'no' to 'pack' journalism. Newspaper Research Journal, 35(2), 40-54. doi:10.1177/073953291403500204

Kiousis, S. (2002). Interactivity: A concept explication. New Media \& Society, 4(3), 355-383. doi:10.1177/ 146144480200400303

Kreiss, D., \& McGregor, S. C. (2018). Technology firms shape political communication: The work of $\mathrm{Mi}$ - crosoft, Facebook, Twitter, and Google with campaigns during the 2016 US presidential cycle. Political Communication, 35(2), 155-177. doi:10.1080/ 10584609.2017.1364814

Kuhn, R., \& Nielsen, R. K. (Eds.). (2014). Political journalism in transition: Western Europe in a comparative perspective. London: IB Tauris.

Larsson, A. O., Kalsnes, B., \& Christensen, C. (2017). Elite interaction: Public service broadcasters' use of Twitter during national elections in Norway and Sweden. Journalism Practice, 11(9), 1137-1157. doi:10.1080/17512786.2016.1234943

Lasorsa, D. L., Lewis, S. C., \& Holton, A. E. (2012). Normalizing Twitter: Journalism practice in an emerging communication space. Journalism Studies, 13(1), 19-36. doi:10.1080/1461670X.2011.571825

Lawrence, R. G., Molyneux, L., Coddington, M., \& Holton, A. E. (2014). Tweeting conventions: Political journalists' use of Twitter to cover the 2012 presidential campaign. Journalism Studies, 15(6), 789-806. doi:10.1080/1461670X.2013.836378

Lazarsfeld, P. F., \& Merton, R. (1954). Friendship as a social process: A substantive and methodological analysis. In M. Berger, T. Abel, \& C. H. Page (Eds.), Freedom and control in modern society (pp. 18-66). New York, NY: Van Nostrand.

Lewis, S. C. (2012). The tension between professional control and open participation: Journalism and its boundaries. Information, Communication \& Society, 15(6), 836-866. doi:10.1080/1369118X.2012. 674150

Lewis, S. C., Zamith, R., \& Hermida, A. (2013). Content analysis in an era of big data: A hybrid approach to computational and manual methods. Journal of Broadcasting \& Electronic Media, 57(1), 34-52. doi:10.1080/08838151.2012.761702

Margolis, M., \& Resnick, D. (2000). Politics as usual: The cyberspace "revolution" (1st ed.). London: Sage

Matusitz, J., \& Breen, G. M. (2012). An examination of pack journalism as a form of groupthink: A theoretical and qualitative analysis. Journal of Human Behavior in the Social Environment, 22(7), 896-915. doi:10.1080/10911359.2012.707933

McGregor, S. C., \& Molyneux, L. (2018). Twitter's influence on news judgment: An experiment among journalists. Journalism. doi:10.1177/1464884918802975

McPherson, M., Smith-Lovin, L., \& Cook, J. M. (2001). Birds of a feather: Homophily in social networks. Annual Review of Sociology, 27(1), 415-444. doi:10.1146/annurev.soc.27.1.415

Meraz, S. (2009). Is there an elite hold? Traditional media to social media agenda setting influence in blog networks. Journal of Computer-Mediated Communication, 14(3), 682-707. doi:10.1111/j.10836101.2009.01458.x

Meraz, S., \& Papacharissi, Z. (2013). Networked gatekeeping and networked framing on \#Egypt. The International Journal of Press/Politics, 18(2), 138-166. 
doi:10.1177/1940161212474472

Molyneux, L. (2015). What journalists retweet: Opinion, humor, and brand development on Twitter. Journalism, 16(7), 920-935. doi:10.1177/ 1464884914550135

Molyneux, L., \& Mourão, R. R. (2019). Political journalists' normalization of Twitter: Interaction and new affordances. Journalism Studies, 20(2), 248-266. doi:10.1080/1461670X.2017.1370978

Mourão, R. R. (2015). The boys on the timeline: Political journalists' use of Twitter for building interpretive communities. Journalism, 16(8), 1107-1123. doi:10.1177/1464884914552268

Nuernbergk, C. (2016). Political journalists' interaction networks. Journalism Practice, 10(7), 868-879. doi:10.1080/17512786.2016.1162669

Nuernbergk, C., \& Conrad, J. (2016). Conversations and campaign dynamics in a hybrid media environment: Use of Twitter by members of the German Bundestag. Social Media + Society, 2(1). doi:10.1177/ 2056305116628888

Ottovordemgentschenfelde, S. (2017). 'Organizational, professional, personal': An exploratory study of political journalists and their hybrid brand on Twitter. Journalism, 18(1), 64-80. doi:10.1177/ 1464884916657524

Parmelee, J. H. (2013). Political journalists and Twitter: Influences on norms and practices. Journal of Media Practice, 14(4), 291-305. doi:10.1386/ jmpr.14.4.291_1

Parmelee, J. H., \& Deeley, D. (2017). Florida political reporters interact rarely online. Newspaper Research Journal, 38(1), 104-118. doi:10.1177/ 0739532917698438

Parmelee, J. H., Roman, N., Beasley, B., \& Perkins, S. C. (2019). Gender and generational differences in political reporters' interactivity on Twitter. Journalism Studies, 20(2), 232-247. doi:10.1080/1461670X. 2017.1364140

Przeworski, A., \& Teune, H. (1970). The logic of comparative social inquiry. New York, NY: Wiley.

Rogstad, I. D. (2014). Political news journalists in social media. Journalism Practice, 8(6), 688-703. doi:10.1080/17512786.2013.865965

Russell, F. M., Hendricks, M. A., Choi, H., \& Stephens, E. C. (2015). Who sets the news agenda on Twitter? Digital Journalism, 3(6), 925-943. doi:10.1080/ 21670811.2014.995918

Semetko, H. A. (1996). Political balance on television.
Campaigns in the United States, Britain, and Germany. Harvard International Journal of Press/Politics, 1(1), 51-71. doi:10.1177/1081180X96001001005

Siapera, E., Boudourides, M., Lenis, S., \& Suiter, J. (2018). Refugees and network publics on Twitter: Networked framing, affect, and capture. Social Media and Society, 4(1). doi:10.1177/2056305118764437

Singer, J. B. (2005). The political j-blogger: 'Normalizing' a new media form to fit old norms and practices. Journalism, 6(2), 173-198. doi:10.1177/ 1464884905051009

Stromer-Galley, J. (2014). Presidential campaigning in the internet age. Oxford: Oxford University Press. doi:10.1093/acprof:oso/9780199731930.001.0001

Tandoc, E. C., Jr., \& Vos, T. P. (2016). The journalist is marketing the news. Journalism Practice, 10(8), 950-966. doi:10.1080/17512786.2015.1087811

Tobitt, C. (2018). Top female lobby journalists say 'we need to show it's not an all-boys' club' on International Women's Day. UK Press Gazette. Retrieved from https://www.pressgazette.co.uk/top-femalelobby-journalists-say-we-need-to-show-its-not-an-allboys-club-on-international-womens-day

Usher, N., Holcomb, J., \& Littman, J. (2018). Twitter makes it worse: Political journalists, gendered echo chambers, and the amplification of gender bias. The International Journal of Press/Politics, 23(3), 324-344. doi:10.1177/1940161218781254

Van Aelst, P., \& De Swert, K. (2009). Politics in the news: Do campaigns matter? A comparison of political news during election periods and routine periods in Flanders (Belgium). Communications, 34(2), 149-168. doi:10.1515/COMM.2009.011

Vergeer, M. (2015). Peers and sources as social capital in the production of news: Online social networks as communities of journalists. Social Science Computer Review, 33(3), 277-297. doi:10.1177/ 0894439314539128

Watts, D. J., \& Rothschild, D. M. (2017). Don't blame the election on fake news. Blame it on the media. Columbia Journalism Review. Retrieved from https://www.cjr.org/analysis/fake-news-media-elec tion-trump.php

Wihbey, J. (2018). Which factors influence how news is produced? Research on structural problems in media. Northeastern University NU Lab. Retrieved from https://web.northeastern.edu/nulab/which-factorsinfluence-how-news-is-produced-research-on-struc tural-problems-in-media

\section{About the Author}

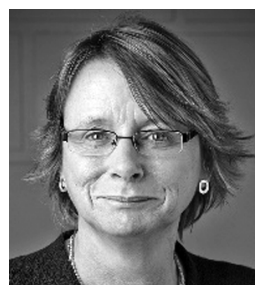

Kelly Fincham is a PhD candidate at Dublin City University and Associate Professor in the Department of Journalism, Media Studies and Public Relations at Hofstra University. 